\title{
公団鈴が峰第 2 住宅団地開発計画における地形造成と配置計画の特徵に関する研究 \\ Study of plan land forming and layout plan in Collective Housing development of Suzugamine town
}

\author{
下田元毅* 篠沢 健太**
}

\author{
Motoki SHIMODA Kenta SHINOZAWA
}

\begin{abstract}
In this research, we will clarify the characteristics that the terrain gradient has given to the housing plan, open space, placement plan of pedestrian street, roadway, parking lot, for residential complex planned for de-standard design. Based on the result, how to incorporate the natural environment "consciously" in the multi-family housing plan. It aims to find out that clue. The research method will organize the characteristics of development and development of wide area development.

After that, I grasped the transition of the first plan to the final plan (nine total plan) which considered housing arrangement plans. (1) Resident building placement, (2) open space, (3) placement plan of the pedestrian street · roadway · parking lot, the structure of the residence building, characteristics of the living space and the influence the terrain has on the placement plan.

As a result, it was found that studies are underway to overcome the standard design by using the terrain gradient after the clay.Also, the design standard ground height of the residence was not set by the placement plan. In other words, it was found that the layout of the residence was done first, and then the terrain after the clay was adjusted to the residence according to the arrangement, and the final ground was formed.
\end{abstract}

Keywords: landform, Layout plan,residential building, land forming キーワード：地形, 配置計画, 住棟, 土地造成

\section{1. 背景と目的}

都市の人口増加による住宅需要に対応寸るため, 高度経済成長 期にはニュータウン（以下，NT と示す）が開発され，多くの集 合住宅が建設された。NTの多くは丘陵地を造成して開発されて おり, 開発の過程において地域の自然環境が NT のオープンスペ 一スの計画等に組み込まれている過程が明らかになってきた 1,2)。さらに，集合住宅地開発が開発前の自然環境の特徵を内在， 継承していることが明らかになりつつある 334$)$ 。高度経済成長期 当初の NT 計画では，技術・経済的制約を受けつつ自然環境の特 徵が「非意図的」に空間計画に組み込まれ 4), その後 NT の都市 機能や空間構造と計画が「意図的」に関係をもつよう移行してい くことが報告されている5 ${ }^{5}$ 。

本研究は, 集合住宅団地の開発過程で集合住宅団地の開発過程 で 1973 年のオイルショックによる高度成長から低成長への経済 転換, 同年に住宅戸数が世帯数を超え, 「脱標準設計 6 ) が求めら れた社会構造の転換期」において, 意図的に自然環境 (地形) を組 み込みながら計画を行った時期の集合住宅に着目し，自然環境と 社会的背景の変遷の一過程に位置付けることを試みた。

地形と集合住宅の計画に関わる既往研究は, 開発前後の造成地 形が住棟配置やオープンスペースに与えた影響を明らかにした ${ }^{7)}$ 研究や, 団地内のオープンスペーと住棟配置との関連をまとめた ${ }^{8}$ 研究がある。これらは初期のNT 開発・住宅計画が対象時期であり, 脱標準設計が求められた時期でない。対象時期を含む 1953 年から 1993 年の集合住宅において, 坂本らは, 住棟や外部空間と動線, 形態的なまとまりによる住棟の配列に着目し, 設計者の視点から 住戸の集合の仕方そのものを論じた一連の研究 ${ }^{9,10,11)}$ を行ってい るが，住棟の設置性や地形造成との関係についての分析はない。

そこで, 本論では, 脱標準設計を目的に計画された住宅団地を対 象に, 地形勾配が住棟やオープンスペース, 歩行者路・車道・駐車 場の配置計画に与えた特徵を明らかにする。その結果に基づき, 集合住宅計画において自然環境をどのように「意識的」に組み込
んでいくか? 都市縮退時代の郊外集合住宅地再編計画の糸口を見 出すことを目的とする。

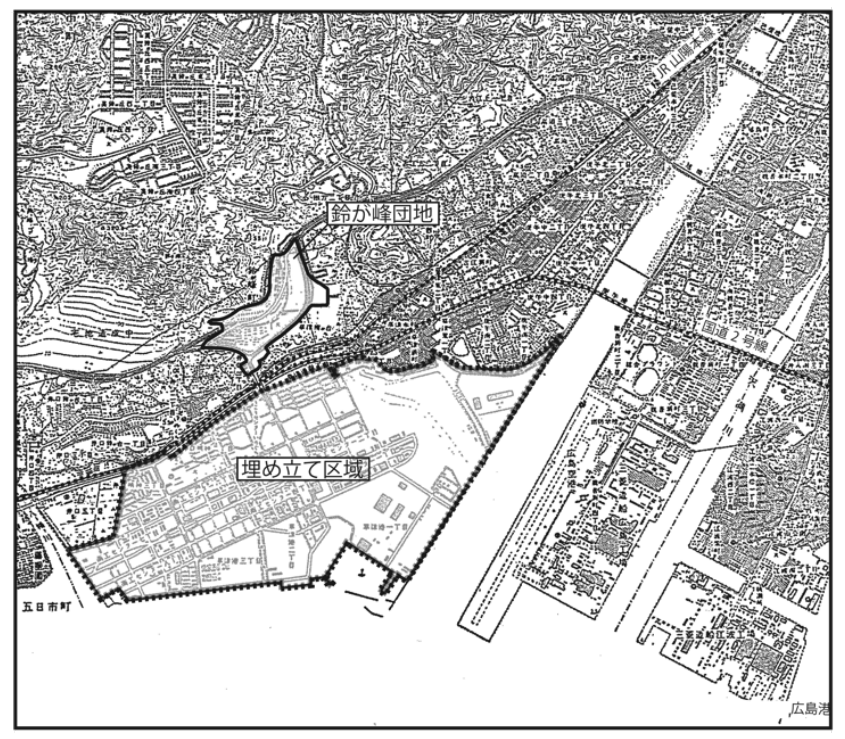

図-1＼cjkstart鈴が峰住宅団地位置と埋立区画

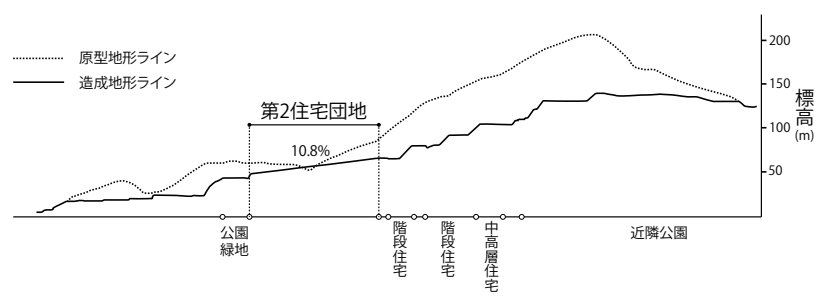

図-2 住棟配置図と基準地盤高さ（造成前後の等高線）

*大阪大学工学研究科地球総合工学専攻 建築都市デザイン学講座 


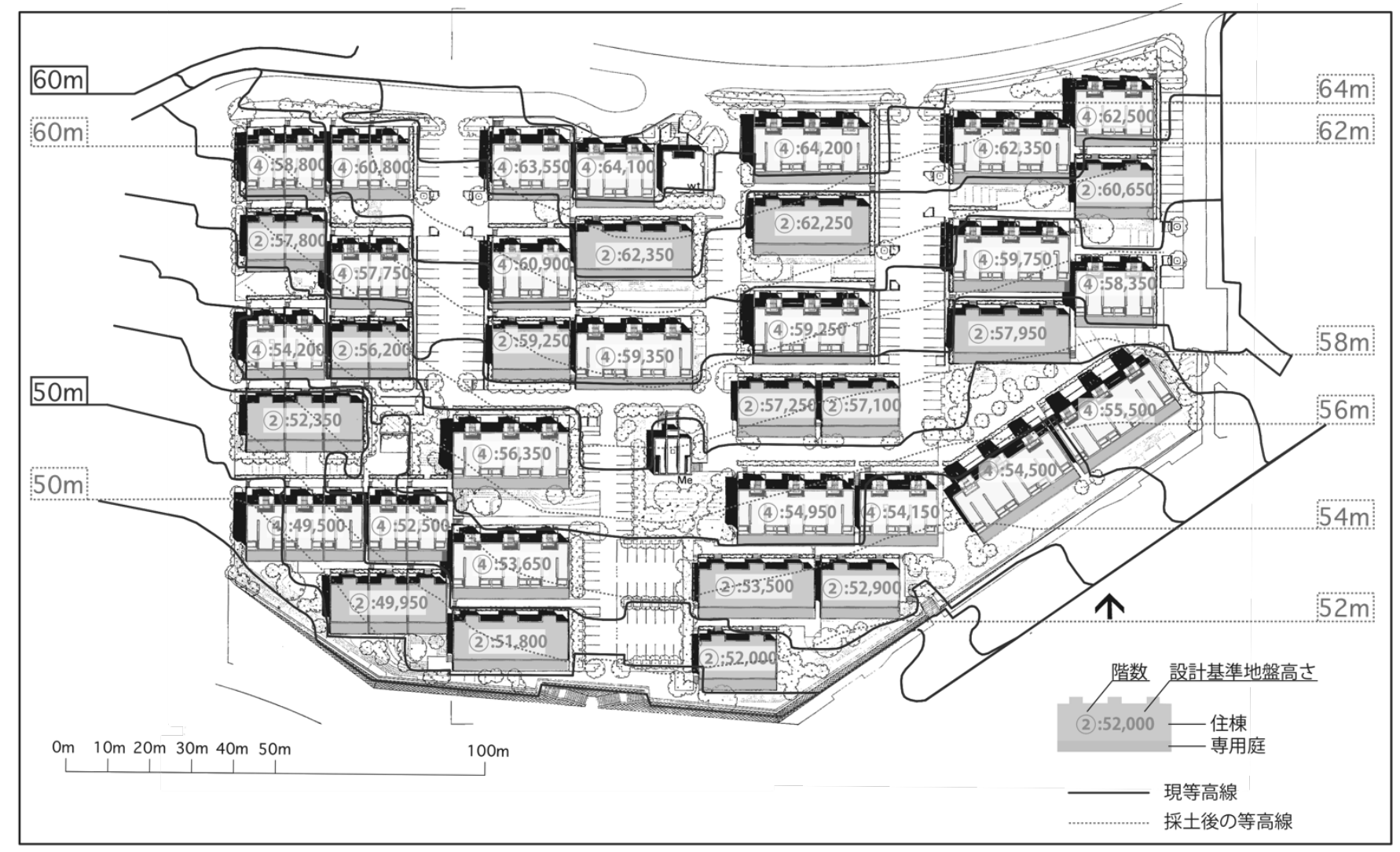

図-3 住棟配置図と設計基準地盤高さ（造成前後の等高線）

\section{2. 対象と研究方法}

対象として，広島県広島市西区鈴が峰山に開発された鈴が峰団 地内の 1 街区である鈴が峰第 2 住宅 (以下第 2 住宅) を選定した。 第 2 住宅は 2 階建て住棟と 4 階建て住棟で構成された総戸数 294 戸の分譲住宅団地で，1980 年に竣工した。設計は藤本昌也が率い る現代計画研究所である。

日本住宅公団における開発は数多く存在することから，本論の 対象とする時代背景である昭和 50 年代の 1975 年-1984 年の団地 開発から「量から質への設計の取り組みが行われ，多様化した需 要の把握, 居住者ニーズへの的確な対応が重視され, 立地対応や 需要喚起が設計テーマ」 ${ }^{13)}$ として取り上げられている 13 の団地の 中から下記の選定理由(1)～(4)を踏まえ第2住宅を選定した(表-1)。 (1)埋立とニュータウン開発がセットで行われているということ， (2)採土場で地質が岩盤という造成に対し，制約がかかる厳しい条 件下での計画であったということ, (3)計画案, 図面が残っており, その中に標準設計と比較した記述が残されているということ, (4) 配置計画が地形勾配を意識して行われたこと $\left.{ }^{12}\right)$ で, 前提として与 えられた地形をさらに宅盤造成せずに，配置と住棟計画の工夫を 把握しうると判断したからである。

研究方法は, まず第 2 住宅計画を含む広域の開発の経緯・造成 の特徵を整理する。その上で第 2 住宅の住棟配置を検討した第 1 次案〜最終案(全9案)の変遷を(1)住棟配置, (2)オープンスペース, (3)歩行者路・車道・駐車場のそれぞれについて把握し，配置計画と くに住棟構成及び居住空間の特徵および地形が配置計画に与えた 影響について詳細に検証した。

\section{3. 鈴が峰第 2 住宅の特徵}

（1）西部開発事業における鈴が峰団地開発の経緯と特徵

鈴が峰団地は，広島市中心部から西方約 $7 \mathrm{~km}$ の広島湾に面寸る鈴 表-1＼cjkstart対象団地リスト

\begin{tabular}{|c|c|c|c|c|c|c|c|c|}
\hline 団地名 & $\begin{array}{l}\text { 団地 } \\
\text { 面皘 } \\
\text { (ha) }\end{array}$ & \begin{tabular}{|l|} 
售戸 \\
(数 \\
(尹)
\end{tabular} & \begin{tabular}{|l}
$\lambda$ 入㤟 \\
開始 \\
(年)
\end{tabular} & 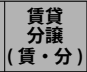 & $\begin{array}{l}1 \\
\text { 埋立開発 } \\
\text { (有・無) }\end{array}$ & 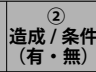 & $\begin{array}{c}3 \\
\text { 標準設計 } \\
\text { (有·無) }\end{array}$ & $\begin{array}{c}\text { (4) } \\
\text { 地形勾配 } \\
(\text { 有・無) }\end{array}$ \\
\hline 川口芝園団地 & 9.1 & 2,454 & 昭和 53 & 賃 & \begin{tabular}{|l|} 
無 \\
\end{tabular} & \begin{tabular}{|c|} 
無 \\
\end{tabular} & \begin{tabular}{|l|} 
無 \\
\end{tabular} & \begin{tabular}{|c|lll} 
無 \\
\end{tabular} \\
\hline 森ノ宮第二団地 & 4.2 & 1,659 & 昭和 51 & 賃 & 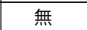 & 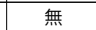 & - & \begin{tabular}{c|c|l} 
無 \\
\end{tabular} \\
\hline 鈴が峰第二住宅 & 1.2 & 294 & 昭和 55 & 分 & 有 & 有 & 有 & 有 \\
\hline $\begin{array}{l}\text { 金沢シーサイドタウン } \\
\text { 业木一丁目 }\end{array}$ & 18.6 & 2,400 & 昭和 53 & 賃·分 & 有 & 無 & 有 & 無 \\
\hline タウンハウス諏訪 & 1.3 & 58 & 昭和 54 & 分 & 無 & 無 & 有 & 有 \\
\hline 東大路高野 & 9.0 & 1,100 & 昭和 54 & 分 & 無 & 無 & - & 無 \\
\hline 八事表山 & 0.6 & 50 & 昭和 55 & 分 & $\begin{array}{l}\text { 無 } \\
\end{array}$ & $\begin{array}{l}\text { 無 } \\
\end{array}$ & - & 有 \\
\hline $\begin{array}{l}\text { ハークハイッ } \\
\text { 平尾山荘 }\end{array}$ & 2.3 & 230 & 昭和 56 & 分 & $\begin{array}{l}\text { 無 } \\
\end{array}$ & $\begin{array}{l}\text { 無 } \\
\end{array}$ & 有 & 有 \\
\hline 入船北エステート & 5.3 & 800 & 昭和 56 & 分 & $\begin{array}{l}\text { 無 } \\
\end{array}$ & 無 & - & $\begin{array}{l}\text { 無 } \\
\end{array}$ \\
\hline 木場公園三好住宅 & 0.5 & 96 & 昭和 57 & 賃·分 & $\begin{array}{lll}\text { 無 } \\
\end{array}$ & $\begin{array}{ll}\text { 無 } \\
\end{array}$ & - & $\begin{array}{ll}\text { 無 } \\
\end{array}$ \\
\hline 淀川 & 35.6 & 2,100 & 昭和 58 & 賃·分 & 無 & 無 & - & 無 \\
\hline 光が丘パークタウン & 186 & 7,500 & 昭和 58 & 賃·分 & 無 & $\begin{array}{l}\text { 無 } \\
\end{array}$ & - & 無 \\
\hline $\begin{array}{l}\text { リバーサイト } \\
\text { ともぶち }\end{array}$ & 7.0 & 1,200 & 昭和 59 & 賃·分 & 無 & 無 & - & 無 \\
\hline
\end{tabular}

が峰山体縁辺部に位置するニュータウンである(図 1)。土地所有者 への換地処分による戸建住宅の他，9 タイプの集合住宅が建ち並 ぶ。

当敷地はかつて急傾斜の山林であったが，広島市西部開発事業 に伴う湾岸部埋立用の採土場となった。広島市西部開発事業は, 昭和 41（1966）～57（1982）年度に行われた広島市の単独事業で 「大規模地方開発都市」 ${ }^{14,15)}$ という事業方針に基づいて，山地部造 成 (住宅地の確保) と臨海部埋立 (経済・流通拠点の形成) の「陸・ 海」の開発事業がセットで行われた。

その採土跡地に良質な住宅を供給する目的で, 昭和 43 年 3 月に 新住宅市街地開発法に基づく住宅団地が都市計画決定・事業決定 された。扇状地に都市機能が集中する広島市では, 都市用地を求 めて沖合と山側一開発を進めなくてはならない土地利用の制限下 にあった。西部開発地域は, 住宅用地と経済・流通拠点を同時に用 
地確保する広島市における戦後開発の起点 ${ }^{14)}$ と言える。

計画面積は計 54. 1ha，土地利用の面積割合は住宅用地 27. 5ha， 車道用地 $12.9 \mathrm{ha}$, 公園緑地 $10.9 \mathrm{ha}$, 公共用地 $2.8 \mathrm{ha}$, 計画戸数 2,538 戸, 計画人口約 1 万人であった。敷地南側の低地部にはJR 山陽本 線, 広島電鉄宮島線, 国道 2 号線が, 北には西広島バイパス (自動 車専用車道)が走り, 都心部と良好な交通アクセスで結ばれた郊外 住宅地として一等地の条件を備えていた。

\section{（2）第 2 住宅の造成の特徵}

広島市西部事業開発における土地造成は，広島市土木部が担当 した。鈴が峰団地を含む開発事業対象地は鈴が峰山体の縁辺部に 位置し, $18 \sim 24^{\circ}$ の比較的なだらかな斜面と $30 \sim 45^{\circ}$ の急峻な斜 面地に二分されていた。基盤地層は花崗岩で，採土は岩盤層まで 及び，採土の結果，山側の $45^{\circ}$ に近い急勾配斜面と，海側の $1 / 10$ の緩勾配斜面が削り残された(図 2 )。

最大傾斜 $45^{\circ}$ にもなる急勾配斜面には，階段住宅(市営鈴が峰 西アパート)や, 上層部のブリッジで周囲とつながる板状住宅など, 急峻な地形を克服するよう住棟配置や住棟タイプが工夫された。

第 2 住宅は，海側に残された $10 \%$ 勾配の斜面上に計画された (図 3)。採士後の地形に新たに「宅盤を刻む」造成は行わず，住戸 配置計画に合わせて $10 \%$ 勾配の岩盤層上に平均 $1 \mathrm{~m}$ の盛土を行い,

「住棟に地形をすりつける」かたちで地形処理が行われ, 全ての住 棟の設計基準地盤高が異なっている。かつての自然環境の地形・ 地質条件 (岩盤層までの深さ・位置) が西部事業開発時の採土によ って顕在化し, その採土後の地形を再度造成せずに, 地形を活か した住宅配置計画が行われている。

\section{4. 住棟構成の基本的な特徵}

第 2 住宅の配置計画については, 鈴が峰中高層団地基本計画報 告書(1974, 以下基本計画)」 ${ }^{16)}$ と広島鈴が峰団地 A ブロック配置基 本設計報告書(1977 年, 以下 A ブロック基本設計 ${ }^{17}$ )の 2 つの報告 書に基づいて分析を行った。

基本計画は，広島市より委託を受けた現代計画研究所が鈴が峰 団地全体の街区計画, 住戸数, 街区毎の住棟形式, 交通計画等をま とめたもので，マスタープランとしての性格が強い。報告書内に おける第 2 住宅の街区における内容は, 低層ボリュームの居住構 成が検討され，採土後の地形を活かし，海への眺望性を意図して いることが伺えるが詳細な間取りの記述はなく, 配置計画につい ても検討はされていない。

A ブロック基本設計は, 現在の第 2 住宅の間取り, 住棟構成を含 めた配置基本計画案をまとめ, この報告書を通して配置計画が決 まっている。報告書内に計画当初から完成に至る配置計画図全 9 案が残っており, 配置計画の変遷を把握できる。住棟配置の前に,
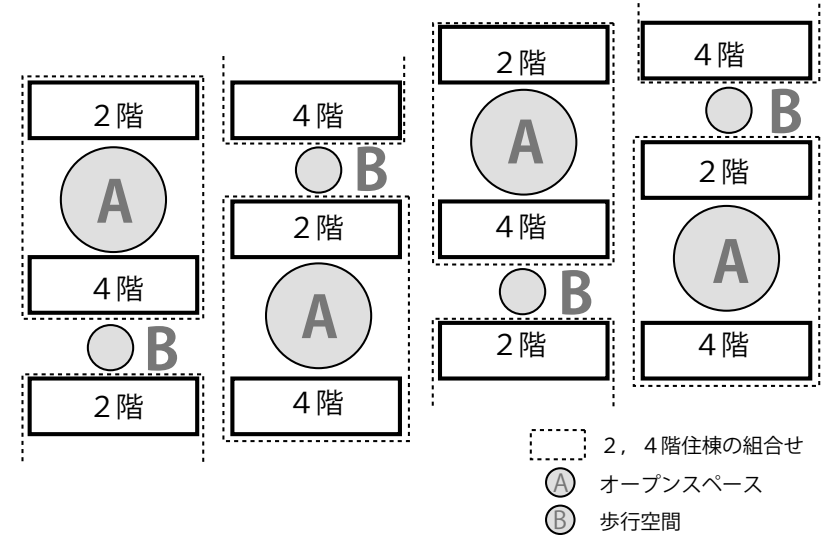

図-4 住棟配置モデルの基本パタン

居住構成，間取りが決まっていたが，その配置は決まっていなか つた。また，南面並行配置でありながら平凡な標準設計にならな いよう, 家並みの変化が意識されたプラン及ひ配置が計画された。 A ブロック基本計画による住棟構成の基本的な特徵は, 下記のとお りである。

\section{(1) ちどり型配置システム}

第 2 住宅の住棟配置では最終的に, 2 階建住棟と 4 階建住棟の 組み合わせによる「ちどり型配置システム」が採用された ${ }^{18)}$ 。 の配置は, A ブロック基本設計によると「(1)密度感ある住棟間の路 地空間と, 住棟間隔が離れた, 広がりある隣棟空間によって, 疎密 の変化のあるオープンスペースを創出し, (2)視界の広がりやスカ イラインの変化など, 魅力ある歩行空間・居住空間を形成, さらに (3)歩行空間, 生活空間, オープンスペースを多様化しつつ, 段階的 に連結する構成」と明記されている(図 4)。

\section{（2） 2 階建住棟と 4 階建住棟の組み合わせ形式}

2 階住棟と 4 階住棟を組み合わせた住棟形式の特徵が，公団の 標準設計と比較して述べられている。標準設計との比較を表にま とめた(表-2)。記述からは，脱標準設計との比較が明確に記述さ れており，その意図を垣間見る事ができる。(1)全住戸の $40 \%$ 海 への眺望を享受できる (公団標準棟 $5 \mathrm{~F}$ の場合の海への眺望: $20 \%$ )。 (2)全住戸の $60 \%$ が専用庭を持つことができ，さらに南庭に加えて 北庭(サービスヤード)を持つことができ, 分譲の場合の高い庭付 き住戸の需要に応えられる（公団標準棟5F想定）。

(3)傾斜地のため, 通路からのプライバシーが比較的容易に確保で きるだけでなく, 庭の中からの開放性も確保できる(コートハウス 型では塀が高くなり，屋外環境が閉鎖的となる）。(図 5) (表 2)

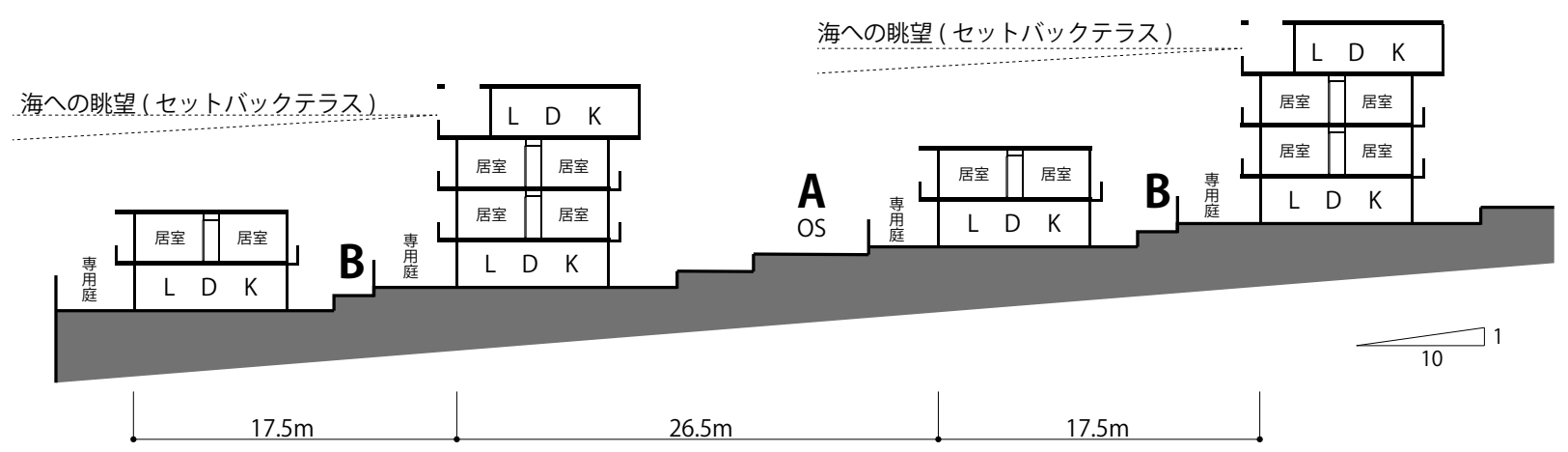

図-5＼cjkstart住棟の組合せ構成図 
表-2 住棟の組合せ構成図

\begin{tabular}{|c|c|c|}
\hline & 第 2 住宅 & 標準設計 \\
\hline 海への眺望（割合） & 全住戸の 40\% & $\begin{array}{l}\text { 全住戸の 20\% } \\
\text { (公団標準棟 5F 想定) }\end{array}$ \\
\hline 庭 ( 分袞の場合 ) & $\begin{array}{l}\text { 全住戸の } 60 \% \text { が } \\
\text { 専用南庭十北庭を } \\
\text { 持つことができる }\end{array}$ & $\begin{array}{l}\text { 全住戸の 20\% } \\
\text { (公団標準棟 5F 想定) }\end{array}$ \\
\hline プライバシー & $\begin{array}{l}\text { プライバシーを確保 } \\
\text { しながら，開放性あ } \\
\text { る庭を確保 }\end{array}$ & $\begin{array}{c}\text { 塀が高くなり，閉銷 } \\
\text { 的な屋外環境になる } \\
\text { (コートハハス型想定) }\end{array}$ \\
\hline
\end{tabular}

3 項目による比較を分析すると, 庭の項目以外の 2 つは, 斜面地 である条件を活用して実現できている内容であることが分かる。 地形 (斜面)を積極的に組み込んだ検討（ちどり型配置及び 2,4 階 住棟の組み合わせ形式）と意図によって, 標準設計では獲得出来 ない海への眺望性やプライバシーを確保しながら開放性を持った 庭を獲得出来ていることを把握できる。

\section{(3) 住棟構成と地形の関係}

A ブロック基本設計による住棟構成の特徽をみてみると「2 階建 住棟と 4 階建住棟の組み合わせ形式」による「ちどり型配置シス テム」によって, 明確な標準設計との比較をみることができ, 地形 を積極的に活用した計画であることが確認できた。地形を操作す るのでなく, 地形を活用して配置と住棟の組み合わせによる工夫 を把握できた。

\section{5. 配置計画の変遷}

次に鈴が峰第2住宅の配置計画第1次案から最終第9案の変遷か ら配置計画の特徵を把握し，地形がどのように配置計画に影響を 与えたかを分析する(図7)。配置計画の特徵を明確にするため, (1)住棟配置, (2)オープンスペース, (3)歩行者路・車道・駐車場な

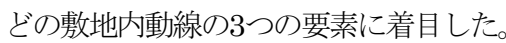

3要素は，既述のAブロック基本計画に明記される「ちどり型 配置システム」の(1)〜(3)の説明文から抽出した。第2住宅におけ る「地形」は操作しうる対象ではなく，デフォルトであり，地形 の影響が配置に明確に合われていることを把握するには有効な 3 要素であると判断した。配置計画の変遷を把握することによっ て, 前提として与えられた地形を宅盤造成せずに, 配置と住棟計 画の詳細な検討を把握する。

\section{(1) 第 1 次案}

第 1 次案は敷地図及び地形図なしで検討が行われており，ちど り型配置によるの配置関係の検討に重点が置かれている。第 1 次 案の時点ですでにちどり型配置と 2,4 階建住棟を基本ユニットと するシステムを採用することが決まっていたことが分かる。(1)住 棟配置は東西, 南北の両方向に 2, 4 階建住棟を交互に配置するパ タンがグリットを用いて検討されている。各住棟の東西方向の住 戸数がカウントされている。(2)オープンスペースは接地性の高い 2 階住棟への採光を考慮し, 2 階住棟の南側に 2 グリット, 4 階住 棟の南側に 1 2 グリットの OS を配置している。(3)敷地内動線は この時点では検討されていない。

\section{(2) 第 2 次案}

第 2 次案では敷地図をもとに検討が行われ，住棟からの眺望性 と住棟の接地性から配置が検討されている。(1)住棟配置は 1 次案 の配置パタンを継承しつつ, 第 1 次案では東西方向に平行してい た住棟配置を，住棟からの眺望性を確保するため住棟を南北にず らす検討をしている。(2)オープンスペースでは大きさを SS, SM, SL (敷地南側公園)の 3 段階に分け，2 階住棟を減らして大 きな OS（SM）を生多出している。そのうち, SM と SL の 2 つの OS
る検討をしている。(3)敷地内動線については，各住棟の南北側に 東西方向の歩行者路を通し, クルドサックの車道を南北軸に 2 本 計画している。駐車場の検討はない。

\section{(3) 第 3 次案}

第 3 次案では，採土後の地形の等高線に合わせようとする対応 が車道計画などで読み取れる。住棟配置では採光とプライバシー を考慮した配置検討へと進んでいる。(1)住棟配置では，第 2 次案 の東西方向に交互に 2,4 階住棟を配置したパタンを変更し，南側 の東西列の住棟列を全て 2 階住棟へと変更している。(2)オープン スペースでは第 2 次案の 3 つの規模の OS の検討を取りやめてい る。(3)敷地内動線では全ての車道が住棟にアクセスできる経路が 検討されている。等高線に基づく検討が進み，比較的勾配が急な 敷地西側において車道が斜めに配置された。また歩行者路が敷地 内南北軸 2 本計画された。この案から敷地北側の公道に沿って駐 車場が配置された。

\section{(4) 第 4 次案}

第 4 次案ではじめて敷地図に等高線が描かれ，地形との詳細な 検討が始められた。(1)住棟配置では, 2 次案で検討された敷地北側 東西方向の住棟が全て 4 階住棟となり、この配置は最終案まで踏 襲される。(2)オープンスペースでは、これまで住棟立地していた 場所に 4 か所に大きな OS が検討されている。(3)敷地内動線では, 住棟間の南北に側面の幅員の狭い歩行者路が設けられ，最終案ま で踏襲されている。また第 3 次案で検討された車道案は廃止され, 敷地北側のみに配置されていた駐車場が敷地中央の南北方向 2 か 所に，車道と一体となって配置されている。

\section{(5) 第 5 次案}

1977 年 1 月 13 日に検討された第 5 次案では，住棟表現に専用 庭のラインが記載され，接地性・眺望性に配慮しながら OS を確保 する詳細な検討に入ったことが分かる。主に地区内住民の歩行者 動線が詳細検討され，同時に緊急車両の進入と住棟配置の関係に つても検討が伺える。また，地区内で最も標高の高い北側中央 部に高架水槽が新たに設けられている。(1)住棟配置では第 3 次案 で検討された敷地南側の東西列の住棟が全て 2 階住棟となる。第 3 案でも 2 階住棟が南側に並ぶが，住棟の組み合わせに違いが見 られる。(2)オープンスペースの大きさは若干変わっているが 4 次 案の配置が踏襲されている。(3)敷地内動線では，東側車道が 1 住 棟分東に移動し，車道に沿った駐車場も合わせて移動している。 南北に伸びた主要歩行者路に直交して，東西方向に地区中央を通 る主要歩行者路が設けられ, 緊急車両の進入を考慮したことが読 み取れる。南北軸の歩行者路の配置は 4 次案を踏襲している。

\section{(6) 第 6 次案}

1977 年 1 月 17 日に検討された第 6 次案は，敷地内動線を考慮 しつつオープンスペースも一体的に整備し，地区の中心的な OS を 生み出している。(1)住棟配置では，中央歩行者路北側の住棟と車 道を東西方向に入れ替え, 敷地中央の南北を通っていた車道軸を ずらしている。(3)敷地中央を南北に通る主要車道の北側半分を東 ヘクランクさせて，(2)このクランクに合わせて敷地南側中央に歩 行者路と地区内広場と集会所を一体化したまとまったオープンス ペースを設けている。

\section{(7) 第 7 次案}

第 7 次案は第 6 次案の配置検討を踏襲している。異なる点は,

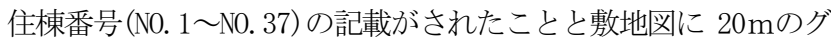
リットが記載された。住棟数が確定し，グリットに沿った，より詳 細な検討が行われた事が分かる。

\section{(8) 第 8 次案の特徵}

第 8 次案は, (3)敷地中央の北側車道の形状が変更され, (1)その 影響を受けた 3 住棟の配置が南に移動している以外に変化はない。 


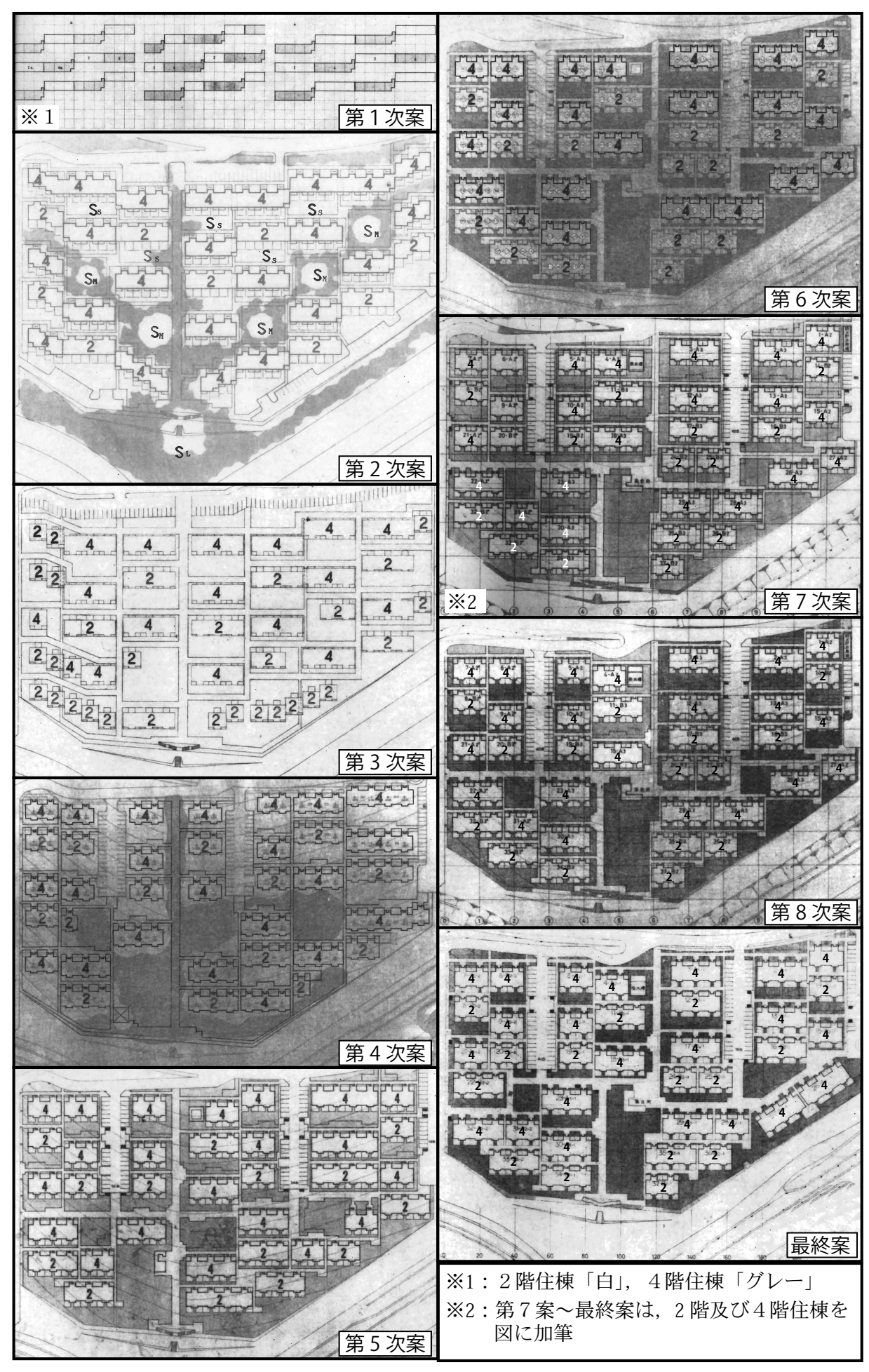

図-6＼cjkstart配置計画の変遷図

最終的に 2 住棟の位置と別の 2 住棟の高さが変更され，広場と一 体となった変化のある歩行空間が創り出された。(1)26, 27 号棟を, 南面配置から等高線に住棟軸を揃えた南東配置に変更している。 また, 22 号棟を 4 階住棟から 2 階住棟に，その南側の 32 号棟を 2 階住棟から 4 階住棟に変更し, 22 号棟を北側に車道幅員分移動し ている。32 号棟の眺望を確保しながら，22 号棟の接地性が高めら れている。(2)22 号棟の移動に伴い北側にあった歩行者路を南側に 移動し, 歩行者路をクランクさせている。(3)住棟配置変更に伴っ て住棟北側に主要歩行者路を設けている。また貯水用地を廃止し,
東側駐車場の台数を増やしている。

\section{6. 考察一最終的な住棟構成の居 住空間の特徵—}

(1) 住棟配置計画と地形の特徵

住棟の配置設計は全 9 案のうち 8 次案まで検討されたが, 第 1 案当 初から 2 階建住棟と 4 階建住棟を 南北に組み合わせて配置するちど り型配置の形式は決定していた。 採土後の地形勾配を前提に住棟配 置、車道、歩専道が比較的柔軟に構 成されていたことがわかる。また 第 3 次 5 次案では, 敷地南北の東 西列を 2, 4 階住棟に統一寸る検討 が行われ, 最終案で敷地北側の東 西列の 4 階住棟配置が採用されて いる。これは, 採土後の地形を活か し，住戸内一の日照を中心とした 検討である。その後, 決定された最 終案では特に住戸内への日照, 歩 車道の検討，OS 位置や住棟との距 離, 緊急車両進入路, 地区外への景 観的配慮を中心に検討が重衫られ ている。

\section{（2）地形調整としての踊り場}

第 2 住宅では各住棟の設計基準 地盤高が事前に決定されてはいな かった。一連の配置検討でも住棟 の地盤設定についての記述はない ことから，住棟配置計画が先導す る形で決定されていた。

採土後の盛土は, 屋外階段の踊 り場や各住棟の北側に「すりつけ」, さらに「踊り場のレベル差が目線 の高さ $(1.5 \mathrm{~m})$ を超えない」 ${ }^{12)}$ ように 設定したため，全ての住棟の設計 地盤高が異なることも相まって,

結果として立体感と奥行きのある 外部空間が創出されたといえる。

\section{（3）オープンスペース・敷地内動}

\section{線と地形の特徵}

OS については, 前半の検討(第 2 次案～第4 次案) において住棟配置 が優先されながらも住棟間の各 OS を繋げようとする検討が共通して みられた。最終的に, 敷地南側半分 の敷地中心の南北軸，敷地南西及 び南東に，住棟を繋ぐ連続した OS が確保された。全検討案に共通して, 採土後の地形の勾配に平行でないOSの繋げ方が検討されていた事 が分かる。敷地内動線計画は，基本的に敷地の地形の勾配に対し て水平・垂直に検討が行われている。この事から住棟及び OS は採 土後の地形勾配を考慮しながら検討されていったことが分かる。

\section{7. まとめと今後の課題}

以上，造成の特徵及び住棟構成の特徵と配置計画と地形の関係 をみてきた事で下記のことが明らかとなった。

(1)住棟配置の前に, ちどり型配置システム, 居住構成, 間取りが決 
定していた。採土後の地形を活かしてこれらの構成を検討する中 で標準設計より $20 \%$ 高い海への眺望が確保され, 住居内のプライ バシーと開放性も同時に獲得している。このことから，採土後の 地形公配を用いることで標準設計を乗り越えようとする検討がさ れていることが分かった。

(2)決定されていた居住構成と配置システム（眺望性と接地性，居 住性）を担保するために, 住棟配置検討が重礼られた。一方, 住棟 の設計基準地盤高は配置計画で設定されていなかった。このこと から, 住棟配置が先に行われ, その後, その配置に合わせて採土後 の地形が住棟に擦り付けられて最終的な地盤が形成されたことが 分かった。この擦り付けによって作られる外部空間の詳細につい ては, 今後の課題であるが, 第 2 住宅において標準設計を乗り越 えていくための住棟構成や外部空間の要素として, 採土後の地形 勾配が大きく関与していたことが分かった。

本論は，わずか一事例に過ぎず，同時代の脱標準設計を標榜し た集合住宅との比較や類型化など今後に向けた課題も多い。しか し, 明確に脱標準設計を目的にし, 標準設計との比較を行いなが ら設計を進めた第 2 住宅は, 今後の研究における基準の手掛かり と成り得ると考える。

謝辞：本論をまとめるにあたって，（株)現代計画研究所の藤本昌 也先生, 今井信博先生には, 資料提供に加え, 計画当時の貴重なお 話しとご指導をご鞭撻をいただいた。関西大学教授の江川直樹先 生には，長時間に渡るヒアリングから住棟と地形の関係について ご指導をいただいた。ここに記して感謝の意を示す次第である。 なお, 本研究は, 科学研究費基盤 (C)「集合住宅地開発における自 然環境構造化過程に関するランドスケープ計画論的研究」(課題番 号 17K08187）による研究の成果である。

\section{補注及び引用文献, 参考文献}

1) 篠沢健太・宮城俊作・根本哲夫（2010）：千里ニュータウンの集合住 宅団地に内在寸る自然環境の構造とその形成過程 : ランドスケープ研 究73(5) p. 731-736

2)根本哲夫・宮城俊作・篠沢健太・岩本芙美代 (2009) : 初期公団住宅の 団地に内在する自然環境の構造とその発現形態 : ランドスケープ研究 72 (5) p. 809-814

3) 篠沢健太・宮城俊作・根本哲夫(2008)：千里ニュータウンの公園緑地内 に内在する自然環境の構造とその発現形態 : ランドスケープ研究71 (5) p. $773-778$

4) 篠沢健太・宮城俊作・根本哲夫(2007)：千里ニュータウンにおける集水 域の構造変容と公園緑地系統の関連 : ランドスケープ研究70 (5) p. 647652

5) 篠沢健太・宮城俊作・城地園子(2015) : 高蔵寺ニュータウン開発計画に及 ぼした自然環境構造の影響 : ランドスケープ研究 70(5) p.647-652

6) 本論対象団地の設計者である藤本昌也氏は住宅白書（1978年）の「量か ら質」の記述, 標準設計の廃止 (1978 年) などから 1 団地設計, 1 住戸毎 の個別設計による標淮設計の間取りでない計画設計を標榜することを 「脱標準設計」と述べている(2017 年 1 月 8 日ヒアリング)。

7)宮城俊作・木下剛(2002）: 団地造園の理論と実践の系譜 : in 都市基盤整 備公団「街とみどりの歩み」編集委員会編(2002）: 街とみどりの歩み一団 地造園 45 年史-, 185-221

8) 根本哲夫 ·宮城俊作 - 篠沢健太 - 岩本葵美代(2009）: 初期公団住宅の団地 に内在する自然環境の構造とその発現携帯 : ランドスケープ研究 72 (5) p. 809-814

9) 足立真・坂本一成·奥山信一(1996) : 集合住宅の空間構成における多様性・ 均質性-現代日本の集合住宅における構成単位とその集合形式に関する 研究- : 日本建築学会計画系論文集 No. 490, p93-102
10) 足立真・坂本一成(1999）：住戸の集合と外部空間の配列による構成形式 一現代日本の集合住宅における構成単位とその集合形式に関する研究 その 2- : 日本建築学会計画系論文集 No. 522, p179-185

11) 足立真・坂本一成(2000): 要素の配列による集合住宅の外形構成-現代日 本の集合住宅における構成単位とその集合形式に関する研究 その $3^{-}$: 日本建築学会計画系論文集 No. 530, p135-142

12) 江川直樹氏 (当時現代計画研究所で第 2 住宅を担当, 現 : 関西大学教授) へのヒアリング(2016 年 11 月 23 日)による

13) 団地 100,独立行政法人都市再生機構 技術・コス卜管理室 設計計画チー 么, 2007 年

14) 昭和 37 年に国土総合開発法をもとに策定・閣議決定した「全国開発総 合計画」に盛り込まれた地域開発政策の名称。

15) 広島広域都市圏推進協議会 (1967) : 大規模地方開発都市「広島」に関寸 る調查報告書-中国地方総合調查会委託報告-

16) 現代計画研究所(1974）: 鈴が峰中高層団地基本計画報告書. 広島市

17) 現代計画研究所 (1977) 広島鈴が峰団地 $\mathrm{A}$ ブロック配置基本設計報告書. 広島市

18）「千鳥型配置システム」が鈴が峰第2住宅における配置の「基本パ夕 ン」であることはAブロック基本計画に明示されている。但し全37棟 全てに共通しているわけではない。37棟のうち4階建住棟4棟で南側に オープンスペースが配置されている。これは(1)住戸数確保のために2階 建住棟から4階住棟数に変更された，(24棟のうち3棟が位置する敷地北 側は最も標高が高く, 海への眺望を確保することが優先されたため, などが考えられるが、詳細については今後の課題である。

19)篠沢健太・吉永健一(2017) : 団地図解 地形・造成・ランドスケープ・住 棟・間取りから読多解く設計思考. 学芸出版社, pp. 144

20) 木下康子・植田実(2014)：いえ 団地 まち 公団住宅 設計計画史 : 住ま いの図書館出版局

21) 日本建築学会編著(1989)：集合住宅計画研究史 : 日本建築学会, 1989

22) 花里俊廣・他(2007) : 空間分類にもとづく集合住宅住戸の変遷に関する 研究 : 住宅総合研究財団研究論文集, N0. 34, 173-184 